\title{
Clinical Features of Late-Onset Circulatory Collapse in Preterm Infants
}

\author{
Jin Hee Jang ${ }^{1}$, Jeongmin Shin ${ }^{1}$, Young Hwa Jung ${ }^{1}$, Chang Won Choi ${ }^{1,2}$, and Beyong Il Kim ${ }^{1,2}$ \\ ${ }^{1}$ Department of Pediatrics, Seoul National University Bundang Hospital, Seongnam, Korea \\ ${ }^{2}$ Department of Pediatrics, Seoul National University College of Medicine, Seoul, Korea
}

\section{ABSTRACT}

Purpose: This study aimed to investigate the incidence and clinical features of lateonset circulatory collapse (LCC) in preterm infants.

Methods: Medical records of 327 preterm infants (born before 32 gestational weeks) admitted to the neonatal intensive care unit of Seoul National University Bundang Hospital between January 2014 and December 2017 were reviewed. LCC was defined as sudden onset of refractory hypotension occurring after 7 days of life without obvious causes, which responded to glucocorticoid administration. Clinical characteristics and outcomes in infants with LCC were compared with those in infants with hypotension associated with identifiable causes, which developed after 7 days of life.

Results: Among 327 preterm infants who enrolled in this study, 65 infants developed hypotension with oliguria after 7 days of life. Among these 65 infants, 35 (53.8\%) met the criteria for LCC and 30 (46.2\%) were diagnosed with hypotension associated with other identifiable causes. No statistically significant differences were observed in the baseline pre- and perinatal characteristics between infants with LCC and those with hypotension associated with other causes. Infants with hypotension associated with other causes showed a higher mortality rate than those with LCC (33.3\% vs. $5.7 \%, P=$ 0.004). The mean gestational age and birth weight of infants with LCC were $27^{+5} \pm 2^{+1}$ weeks and $963 \pm 245 \mathrm{~g}$, respectively. LCC occurred at a mean postnatal age of 18 days. The median body weight at the time of diagnosis of LCC was 1,200 g. No association was observed between LCC and gestational age.

Conclusion: Among preterm infants born before 32 gestational weeks who developed hypotension after 7 days of life, nearly $50 \%$ were diagnosed with LCC without apparent identifiable causes. Infants with LCC showed a lower mortality rate than those with hypotension associated with other causes.

Key Words: Late-onset circulatory collapse; Hypotension; Hydrocortisone; Infant, premature
Received: 30 April 2019

Revised: 16 May 2019

Accepted: 27 May 2019

Correspondence to: Chang Won Choi Department of Pediatrics, Seoul National University Bundang Hospital, 82 Gumi-ro 173beon-gil, Bundang-gu, Seongnam 13620, Korea

Tel: +82-31-787-7286

Fax: +82-31-787-4054

E-mail: choicw1029@gmail.com https://orcid.org/0000-0003-1911-0253
Copyright(c)

By Korean Society of Neonatology.

All right reserved.

This is an Open-Access article distributed under the terms of the Creative Commons Attribution Non-Commercial License (http://creativecommons.org/licenses/ by-nc/4.0), which permits unrestricted non-commercial use, distribution, and reproduction in any medium, provided the original work is properly cited. 
서론

신생아기의 혈압은 임신나이(gestational age), 월경 후 나이 (postmenstrual age), 출생 후 나이(postnatal age) 그리고 체중에 따 라 정상 범위가 다르며 이는 심장근육의 구조 및 기능, 혈관의 탄성 도, 혈액 총량 및 혈액의 점도 등에 영향을 받는 것으로 알려져 있 다 $^{1)}$. 태아기 심실 연합순환에서 출생 후 연속순환으로의 전환은 출 생 직후 호흡에 의한 폐의 팽창을 시작으로, 수일 내지 수주에 걸 쳐 동맥관 및 정맥관의 해부학적 폐쇄, 폐혈관저항의 감소 등의 변 화를 거쳐 진행되는데 이러한 일련의 과정을 과도순환(transitional circulation)이라고 한다 ${ }^{2}$. 이러한 적응과정은 특히 조산아에서 생후 7일 이내 급격히 진행되는데 이 과도순환 시기에는 저혈압 (hypotension)이 발생할 수 있고 특히 극소 저체중출생아(very low birth weight infant)에서 호발하는 것으로 알려져 있다 ${ }^{1,3)}$. Al-Aweel 등 ${ }^{4)}$ 은 극소 저체중출생아에서 생후 첫 24 시간 이내에 많게는 $45 \%$ 까 지 저혈압을 경험하고 이러한 출생 초기 저혈압은 중증 뇌실내출혈 과 관련이 있다고 보고하였다.

과도순환을 거치는 중에 극소 저체중출생아 중 일부는 코티졸 (cortisol)에만 반응하는 저혈압을 경험,6)하는데 이러한 불응성 저혈 압(refractory hypotension)의 원인으로서 출생 초기 미성숙한 시상 하부-뇌하수체-부신 축(hypothalamic-pituitary-adrenal axis)에 대한 연구가 진행되었고, 그 결과 초기 불응성 저혈압이 코티졸 합성과 관 련된 부신의 기능저하와 연관이 있다는 것이 보고되었다감) 또한 생 후 7일 이내에는 혈청 코티졸 수치가 상대적으로 낮은 경우가 많으 나 ${ }^{10)}$ 대부분 생후 2 주 정도에는 부신 기능이 정상으로 회복되는 것 으로 알려져 있어 출생 초기의 부신 기능저하와 관련된 불응성 저혈 압은 출생 초기의 과도순환 과정 이후에는 흔히 관찰되지 않는 것으 로 생각되어 왔다).

그러나 2000년대 초반부터 일본에서 출생 초기의 과도순환 과정 을 잘 넘기고 안정적인 경과를 보이던 조산아에게서 생후 7 일 이후 갑작스럽게 순환부전이 발생한 사례들이 보고 ${ }^{11)}$ 되기 시작하였고 이 러한 순환부전은 코티졸 투여로 해소될 수 있다는 사실을 여러 연구 자들이 보고하였다 ${ }^{12,13)}$. 이후 다수의 임상증례를 바탕으로 이러한 후기 불응성 저혈압은 후기순환부전(late-onset circulatory collapse, LCC)으로 명명되었고, Koyama 등 ${ }^{14}$ 의 제안에 따라 잠정적인 진단 기준이 확립되었다. 즉, $\mathrm{LCC}$ 란 과도순환 과정 이후, 즉 대개 출생 7 일 이후에 안정화된 상태에서 갑작스럽게 발생하는, 핍뇨를 동반 하는 불응성 저혈압으로서 패혈증, 대량출혈 등 순환부전을 초래 할만한 원인을 배제할 수 있으며, 용적확장제 및 수축촉진제에는 반응하지 않고 코티졸에 반응하는 순환부전상태를 말한다 ${ }^{15)}$. 이러 한 잠정적 진단기준을 바탕으로 LCC의 임상양상에 대한 연구 결과 가 잇달아 보고되었다 ${ }^{11,12,15-20)}$. 더불어 LCC가 뇌실주위백질연화증 (periventricular leukomalacia) 및 불량한 신경발달학적 결과와 연관
이 있다는 연구 결과도 보고되었다 ${ }^{17)}$. 그러나 LCC는 아직 명확한 발 병기전 및 객관적 진단기준이 확립되어있지 않고 대부분 일부 동아 시아 지역, 특히 일본에 국한되어 사례가 보고되고 있다는 문제가 있 다 ${ }^{12,17-20)}$.

최근 국내의 조산아 치료 수준이 급격히 향상되면서 예전에 비해 매우 이른 임신나이의 조산아들을 치료하는 경우가 증가하면서 일 본에서 보고되고 있는 것과 유사한, 출생 7일 이후에 갑작스럽게 발 생하고 용적확장제나 수축촉진제에는 반응하지 않으면서 코티졸에 는 반응하는 저혈압 사례를 적지 않게 경험하고 있음에도 불구하고 여전히 LCC에 대한 국내 보고는 매우 부족한 상황이다. 이에 본 연 구에서는 임신나이 32 주 미만의 조산아를 대상으로 LCC의 발병률 및 임상양상을 살펴보고 코티졸에 대한 치료반응과 부신기능저하와 의 관련성 및 그 임상적 중요성에 대해서 알아보고자 하였다.

\section{대상 및 방법}

\section{1. 대상}

2014년 1월부터 2017년 12월까지 분당서울대학교병원 신생아중 환자실에 입원한 원내 출생아로 임신나이 32 주 미만의 조산아를 대 상으로 하였다. 생후 7 일 이내 사망하였거나 주요 선천성 기형이나 염색체 이상이 있었던 환자, 그리고 입원 중 타 병원으로 전원 된 환 자들은 분석에서 제외하였다. 본 연구는 분당서울대학교병원 임상 연구윤리위원회로부터 승인을 득하였고 의무기록을 통한 후향적 연 구로 동의서는 면제되었다(IRB 승인번호: B-1902/522-106).

\section{2. 방법}

총 327 명의 임신나이 32 주 미만의 조산아들 중, 제외기준에 해당 하는 24 명을 제외한 총 303 명의 조산아들이 연구 대상이었다. 이 중 에 생후 7일 이후에 핍뇨를 동반한 저혈압이 발생한 65 명의 조산아 들의 자세한 병력을 의무기록을 통해 후향적으로 조사하였다.

조산아의 주산기 임상적 특성으로 임신나이, 출생체중, 성별, 부 당경량아 유무, 다태아 유무, 분만 방법, 산전 부신피질호르몬 투여 여부, 조기양막파수, 전자간증 및 융모양막염의 유무를 조사하였다. 신생아 합병증(morbidity)으로는 신생아호흡곤란증후군, 폐동 맥고혈압 및 폐출혈 유무, 출생 후 스테로이드 투여 여부, 약물 또는 수술적 치료가 필요했던 동맥관개존증, 패혈증, 중증도 2 단계 이상 의 뇌실내출혈, 낭종성 뇌실주위백질연화증(cystic periventricular leukomalacia) 유무, 갑상선 기능저하증 유무, 중증(severe) 기관지 폐이형성증(bronchopulmonary dysplasia)과 사망 여부를 조사하였 다. 기관지폐이형성증은 2000년 미국 국립보건원에서 제시한 기준 (National Institutes of Health consensus definition)을 사용하였으며, 출생 후 최소 28 일 이상 산소 치료를 시행하였고, 교정연령 36 주 이 
후에도 흡입산소농도 0.3 이상의 산소나 양압환기가 필요한 경우를 중증 기관지폐이형성증으로 정의하였다 ${ }^{21)}$. 뇌실내출혈의 중증도는 Papile의 기준에 따라 구분하였다 ${ }^{22)}$.

혈압은 사지에 cuff를 감고 oscillometer를 이용하는 비침습적 인 방법(non-invasive blood pressure monitoring)으로 측정하였고 (Philips Intellivue MP30, MX450, Philips Electronics North America Corp., Blue Bell, PA, USA), 평균 혈압이 $30 \mathrm{~mm} \mathrm{Hg}$ 또는 이완기 혈 압이 $20 \mathrm{~mm} \mathrm{Hg}$ 미만인 경우를 저혈압으로 정의하였다 ${ }^{19,23)}$. 핍뇨는 시간당 소변량이 몸무게 $1 \mathrm{~kg}$ 당 $1 \mathrm{~mL}$ 미만으로 6시간 이상 지속된 경우로 정의하였다 ${ }^{24}$.

본 센터에서는 부신기능부전과 연관된 저혈압의 임상상에 관한 이전 연구 ${ }^{19}$ 를 바탕으로 2014년 1월부터 생후 7일 이후 발생하는 불 응성 저혈압의 처치에 대하여 표준화된 프로토콜을 적용하였다. 즉 핍뇨를 동반한 저혈압이 발생하는 경우 먼저 용적증량제로서 생리 식염수 $10 \mathrm{~mL} / \mathrm{kg}$ 를 투여하고, 생리식염수 투여에도 불구하고 혈압 이 상승하지 않으면 수축촉진제로서 도파민을 $5 \mathrm{\mu g} / \mathrm{kg} / \mathrm{min}$ 의 속도 로 투여하기 시작하고 혈압이 상승하지 않으면 한 번에 2.5-5 $\mathrm{\mu g} /$ $\mathrm{kg} / \mathrm{min}$ 씩 15 분 간격으로 증량하여 최대 $15 \mu \mathrm{g} / \mathrm{kg} / \mathrm{min}$ 까지 용량을 증가시켰다. 동시에 도파민이 $7.5 \mathrm{\mu g} / \mathrm{kg} / \mathrm{min}$ 이상 필요한 경우에는 도부타민도 $5 \mathrm{\mu g} / \mathrm{kg} / \mathrm{min}$ 의 속도로 추가하고 같은 방법으로 최대 15 $\mu \mathrm{g} / \mathrm{kg} / \mathrm{min}$ 까지 증가시켰다. 도파민과 도부타민 모두 $12.5 \mu \mathrm{g} / \mathrm{kg} /$ $\min$ 까지 증량하였음에도 불구하고 혈압이 상승하지 않는 경우에는 혈청 코티졸 농도를 포함하여 혈액배양검사와 기본혈액검사(complete blood count, C-reactive protein 등)를 시행한 후 하이드로코티 손의 투여 여부를 결정하였다.

LCC는 Kawai ${ }^{15}$ )가 제안한 정의에 따라 (1) 출생 후 7일이상 경과한 시점에서 (2) 비교적 안정적인 순환 상태를 유지하는 중에 (3) 용적 증량제와 $15 \mu \mathrm{g} / \mathrm{kg} / \mathrm{min}$ 이상의 수축촉진제 투여에도 반응을 보이지 않는 갑작스러운 저혈압이 있고 (4) 핍뇨(1 mL/ $\mathrm{kg} / \mathrm{hr}$ 미만) 또는 전 해질 농도 이상(저나트륨혈증: 혈청 $\mathrm{Na}+<130 \mathrm{mEq} / \mathrm{L}$ 또는 고칼륨 혈증: 혈청 $\mathrm{K}+>5.5 \mathrm{mEq} / \mathrm{L}$ )이 있으면서 (5) 저혈압을 유발할 수 있 는 다른 원인(패혈증, 동맥관개존증, 출혈, 괴사성 장염 등)이 배제 된 경우로 6) 하이드로코티손의 투여 후 저혈압과 핍뇨가 회복되는 경우에 진단하였다. 임신나이에 따른 LCC의 발생빈도, LCC와 다른 원인에 의한 저혈압과의 임상적 특성의 차이를 분석하고 LCC의 임 상상을 기술하였다.

LCC로 인한 전신적 및 중추신경계 영향을 평가하기 위한 지표로 저혈압 전후의 환기보조변화와 뇌 영상의 변화를 조사하였다. 뇌 영 상 변화는 de Vries의 분류기준 ${ }^{25}$ 을 바탕으로, LCC 전후로 뇌 초음파 에서 이전에는 관찰되지 않았던 백질 주위의 음영 증가가 새로 발생 하거나 기존의 백질 주위 음영 증가가 악화된 경우 LCC와 관련된 중 추신경계 병변이 발생한 것으로 간주하였다.

LCC에서 하이드로코티손의 투여는 스트레스 용량 $(4 \mathrm{mg} / \mathrm{kg} / \mathrm{day})$
으로 시작하여 혈압이 안정화되어 수축촉진제 투여를 중단할 수 있 게 된 시점에서 $2 \mathrm{mg} / \mathrm{kg} / \mathrm{day}$ 로 감량하여 1-2일간 유지하고 계속 혈 압이 안정적이면 $1 \mathrm{mg} / \mathrm{kg} / \mathrm{day}$ 로 감량하여 1-2일간 유지 후 중단 하였다. 예정된 스케줄대로 하이드로코티손이 감량되어 일주일 이 내에 중단되고 퇴원 시까지 재발하지 않은 경우를 단순후기순환부 전(simple LCC)라 명명하였고 감량하는 과정에서 저혈압이 재발하 여 다시 스트레스 용량으로 증량시킨 경우와 LCC가 두 번 이상 재 발한 경우를 불응성 후기순환부전(refractory LCC)이라 명명하였 다. Refractory LCC에 해당하는 환아들 중, 일부에서는 저용량 ACTH 자극검사(low dose adrenocorticotropic hormone stimulation test [ACTH] stimulation test)를 시행하였다. 하이드로코티손을 투여하기 직전에 기저(baseline) 혈청 코티졸 농도를 측정하고 ACTH $1 \mu \mathrm{g}$ 을 정맥주사로 투여하고 30 분 후에 다시 혈청 코티졸 농도를 측정하였 다. 기준 혈청 코티졸 농도가 $15 \mathrm{\mu g} / \mathrm{dL}$ 이상인 경우를 정상으로 정의 하였고 스트레스 상황에서 코티졸 농도가 $15 \mu \mathrm{g} / \mathrm{dL}$ 이하이면 상대 적인 부신기능부전이 있는 것으로 간주하였다 ${ }^{26}$. 또한 $1 \mu \mathrm{g}$ 의 ACTH 자극 30 분 후 측정한 혈청 코티졸 농도가 $20 \mu \mathrm{g} / \mathrm{dL}$ 이상 상승하는 경 우 또는 기준 혈청 코티졸 농도보다 $9 \mu \mathrm{g} / \mathrm{dL}$ 이상 상승한 경우를 정 상이라고 판단하였다 ${ }^{27,28)}$.

\section{3. 통계분석}

통계 분석은 SPSS for windows version 22.0 (IBM Co., Armonk, $\mathrm{NY}, \mathrm{USA}$ )를 이용하여 분석하였다. 조사된 자료에서 연속 변수의 그 룹 간의 비교는 독립표본 $t$ 검정(Student $t$-test)을 이용하여 평균값 土표준편차로 나타내었고, 비연속 변수의 그룹 간의 비교는 카이 제 곱 검정(chi-square test)을 이용하여 빈도수(백분율)로 나타내었고 기대빈도가 5 미만인 셀이 $20 \%$ 가 넘는 경우에는 피셔의 정확 검정 (Fisher's exact test)를 통해 통계적 유의성을 검증하였다. 모든 검정 에서 $P$ 값이 0.05 미만인 경우 통계학적으로 유의성이 있다고 판단 하였다.

\section{결과}

\section{1. 연구 대상의 임상적 특징}

총 303 명의 연구 대상 조산아들 중 생후 7일 이후에 저혈압과 핍 뇨를 경험한 조산아는 65 명 $(21.5 \%)$ 이었고 이들의 임신나이의 중 간값은 $27^{+4}$ 주(범위, $22^{+6}-31^{+4}$ ), 출생체중의 중간값은 $920 \mathrm{~g}$ (범위, 430-1,960)이었다. 저혈압의 원인이 확인된 경우는 총 30명(46.2\%) 으로 패혈증이 8명, 괴사성 장염이 6명, 폐동맥고혈압이 6명, 동맥관 개존증이 5명, 기타가 5명(cardiac arrest 1명, fatal arrhythmia 2명, tension pneumothorax 1 명, syndrome of inappropriate antidiuretic hormone secretion 1 명)이었다. Kawai ${ }^{15}$ 가 제시한 임상적 진단기준 


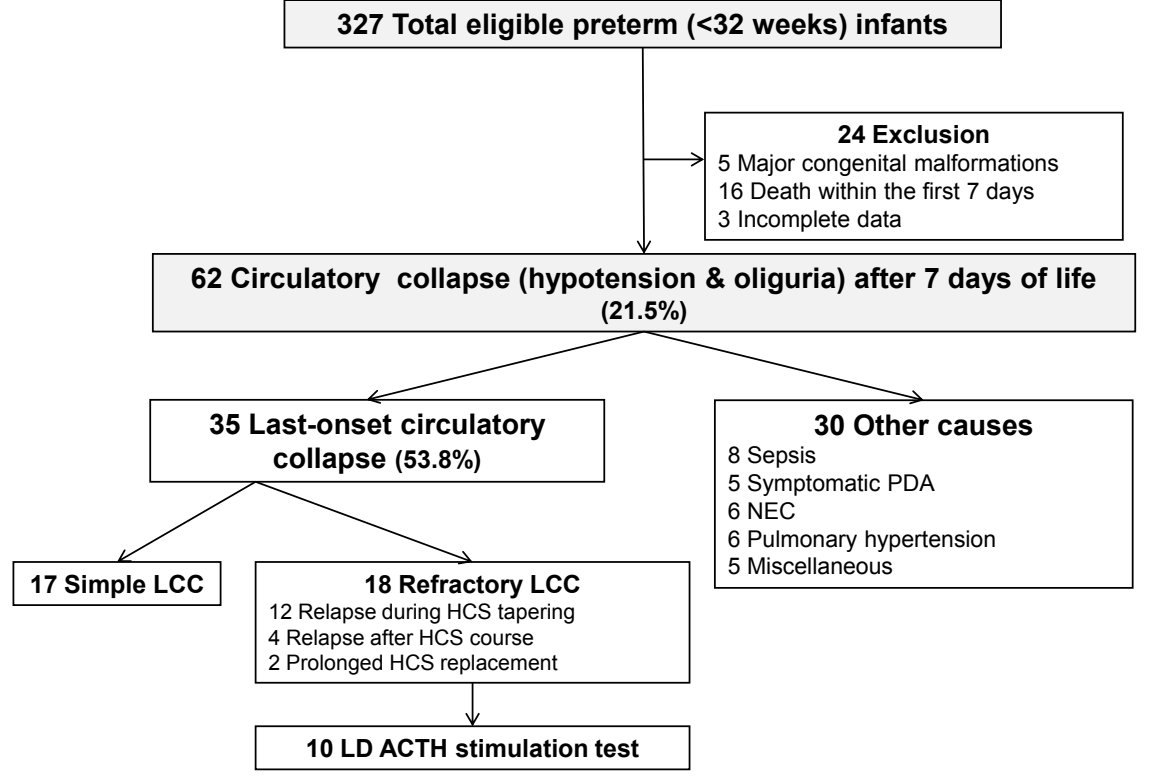

Figure 1. Flow diagram of the study population. Abbreviations: LCC, late-onset circulatory collapse; HCS, hydrocortisone; PDA, patent ductus arteriosus; NEC, necrotizing enterocolitis; LD, low-dose; ACTH, adrenocorticotropic hormone.

에 따라 LCC로 진단된 경우는 총 35 명(53.8\%)이었다. LCC로 진단된 조산아들 중 18 명 $(51.4 \%)$ 은 refractory LCC에 해당되었고 이들 중 10 명에서 저용량 ACTH 자극검사가 시행되었다(Figure 1).

\section{2. 순환부전의 종류에 따른 임상적 특성의 차이}

LCC군 35명과 저혈압의 분명한 원인을 확인할 수 있는 non-LCC 저혈압군 30명을 비교하였을 때, 조산아 임신나이, 출생체중 및 성 별에 유의한 차이는 없었다. 부당경량아로 태어난 경우는 non-LCC 저혈압군에서 유의하게 많았고 다태아로 태어난 경우는 LCC군에서 유의하게 많았다. 그 밖의 주산기 특성에는 유의한 차이가 없었다 (Table 1).

출생 첫날의 저혈압은 non-LCC저혈압군에 비해 LCC군에서 더 많 이 발생하였으나 통계적으로 유의한 차이는 아니었다. 생후 7일 이 후의 저혈압 발생 시점에서의 출생 후 나이, 월경 후 나이와 저혈압 발생 당일의 체중은 두 군 간에 유의한 차이가 없었다. 저혈압 이외 의 임상경과에서는 LCC군에서 non-LCC 저혈압군에 비해 출생 후 부신피질호르몬의 사용, 폐동맥고혈압, 폐출혈, 패혈증, 중증 기관 지폐이형성증과 사망이 유의하게 적었으나 그 밖의 다른 임상경과 는 두 군 간에 유의한 차이가 없었다(Table 1).

\section{3. 후기순환부전군의 임상적 특징}

임신나이 32 주 미만의 조산아 303명 중 LCC의 진단기준에 부합했 던 조산아는 35 명으로 $11.5 \%$ 의 발생빈도를 보였고 28 주 미만의 조 산아 총 85 명을 대상으로 하였을 때는 19명으로 $22.4 \%$ 의 발생빈도
를 보였다. 임신나이대별로 LCC 발생빈도를 확인했을 때, 임신나 이 31 주대 3.4\%, 30주대 8.2\%, 29주대 $11.8 \%, 28$ 주대 8. $1 \%, 27$ 주대 $16.7 \%, 26$ 주대 $25 \%, 25$ 주대 $35.7 \%$ 그리고 24주 이하는 $20 \%$ 였다.

$\mathrm{LCC}$ 로 진단받은 35 명의 조산아들의 임신나이는 $27^{+5} \pm 2^{+1}$ 주, 출 생체중은 $963 \pm 245$ 이었다(Table 1). LCC로 진단받은 총 35 명을 대 상으로 임신나이 분포를 확인했을 때는 임신나이 27 주와 29주대 에서 각각 6명(17.1\%)으로 가장 많이 발생했고, 출생체중 분포는 1,000-1,249 g 구간에서 가장 많이 발생하였다(Figure 2). LCC가 발 생한 시점의 중앙값은 생후 18 일로 월경 후 나이로는 $30^{+5}$ 주였고 당 시 체중의 중앙값은 1,200 이었다(Table 2).

하이드로코티손 첫 투여 48시간 전의 평균혈압의 중간값(범위) 은 $43 \mathrm{~mm} \mathrm{Hg}$ (범위, 37-55)이었고 하이드로코티손 투약 시의 평균 혈압은 $31 \mathrm{~mm} \mathrm{Hg}$ (범위, 17-41)으로 LCC로 인한 저혈압 발생 시 $32.1 \%$ 의 평균혈압 감소를 보였다. 저혈압의 발생 시점으로부터 하 이드로코티손의 첫 투여까지 $2.8 \pm 1.8$ 시간이 소요되었고 첫 하이드 로코티손 투여 후 6.3 4 4.9시간 후 혈압이 정상화되었다.

하이드로코티손 첫 투여 6시간 이전부터 핍뇨를 보인 경우는 16 명(45.7\%)이었으며 하이드로코티손 첫 투여 6시간 전부터 6시간 후 까지 총 12 시간 동안에는 35 명 모두에서 핍뇨가 관찰되었다. 전해 질 불균형과 관련해서는 LCC 발생 전후로 29명(82.9\%)에서 저나트 륨혈증 또는 고칼륨혈증이 관찰되었다. LCC가 발생하면서 새롭게 산소투여, 비침습적 환기 또는 기도삽관이 필요했거나 이미 이전부 터 보조환기를 받고 있었던 경우 이전보다 보다 높은 수준 또는 설정 의 보조환기가 필요했던 경우가 8 명 $(22.9 \%)$ 에서 있었다. LCC 발생 
Table 1. Comparison of Peri- and Neonatal Characteristics between the Late-Onset and Non-Late-Onset Circulatory Collapse Hypotension Groups

\begin{tabular}{|c|c|c|c|}
\hline Characteristic & $\operatorname{LCC}(n=35)$ & Non-LCC hypotension $(\mathrm{n}=\mathbf{3 0})$ & $P$-value \\
\hline Gestational age (wk) & $27^{+5} \pm 2^{+1}$ & $27^{+1} \pm 2^{+3}$ & 0.272 \\
\hline Birth weight (g) & $963 \pm 245$ & $872 \pm 294$ & 0.180 \\
\hline Admission duration (d) & $84.6 \pm 27.7$ & $90.6 \pm 87.4$ & 0.722 \\
\hline SGA & $3(8.6)$ & $9(30)$ & 0.026 \\
\hline Male sex & $18(51.4)$ & $16(53.3)$ & 0.878 \\
\hline Multiple pregnancy & $17(48.6)$ & $6(20.0)$ & 0.016 \\
\hline Cesarean delivery & $28(80.0)$ & $22(73.3)$ & 0.525 \\
\hline Antenatal steroid & $32(91.4)$ & $28(93.3)$ & 0.774 \\
\hline PROM & $16(45.7)$ & $11(36.7)$ & 0.461 \\
\hline HCAM & $16(45.7)$ & $14(46.7)$ & 0.939 \\
\hline Preeclampsia & $2(5.7)$ & $5(16.7)$ & 0.534 \\
\hline Hypotension on the first day & $11(31.4)$ & $8(26.7)$ & 0.067 \\
\hline PMA at the time of hypotension* (wk) & $30^{+3} \pm 2^{+4}$ & $29^{+6} \pm 2^{+6}$ & 0.402 \\
\hline Weight at the time of hypotension* (g) & $1,124 \pm 265$ & $1,065 \pm 437$ & 0.525 \\
\hline PND at the time of hypotension* (d) & $19.8 \pm 1.8$ & $20.6 \pm 2.9$ & 0.072 \\
\hline Postnatal steroid & $4(11.4)$ & $10(33.3)$ & 0.032 \\
\hline RDS & $29(82.9)$ & $28(93.3)$ & 0.200 \\
\hline Pulmonary hypertension & $6(17.1)$ & $13(43.3)$ & 0.021 \\
\hline Pulmonary hemorrhage & 0 & $4(13.3)$ & 0.026 \\
\hline Treated PDA & $9(25.7)$ & $12(40.0)$ & 0.220 \\
\hline Sepsis & $3(8.6)$ & $12(40.0)$ & 0.003 \\
\hline NEC & $5(14.3)$ & $4(13.3)$ & 0.912 \\
\hline ROP stage 3 & $12(34.3)$ & $6(20)$ & 0.070 \\
\hline IVH $2-4$ & $7(20)$ & $8(26.6)$ & 0.525 \\
\hline Cystic PVL & $4(11.4)$ & $4(13.3)$ & 0.816 \\
\hline Hypothyroidism & $10(28.6)$ & $9(30.0)$ & 0.900 \\
\hline Severe BPD & $14(40)$ & $13(43.3)$ & 0.004 \\
\hline Mortality & $2(5.7)$ & $10(33.3)$ & 0.004 \\
\hline
\end{tabular}

Values are expressed as mean \pm standard deviation or number (\%).

*Hypotension after 7 days of life.

Abbreviations: LCC, late-onset circulatory collapse; SGA, small for gestational age; PROM, premature rupture of membrane; HCAM, historical chorioamnionitis; PMA, postmenstrual age; PND, postnatal day; RDS, respiratory distress syndrome; PDA, patent ductus arteriosus; NEC, necrotizing enterocolitis; ROP, retinopathy of prematurity; IVH, intra-ventricular hemorrhage; PVL, periventricular leukomalacia; BPD, bronchopulmonary dysplasia.
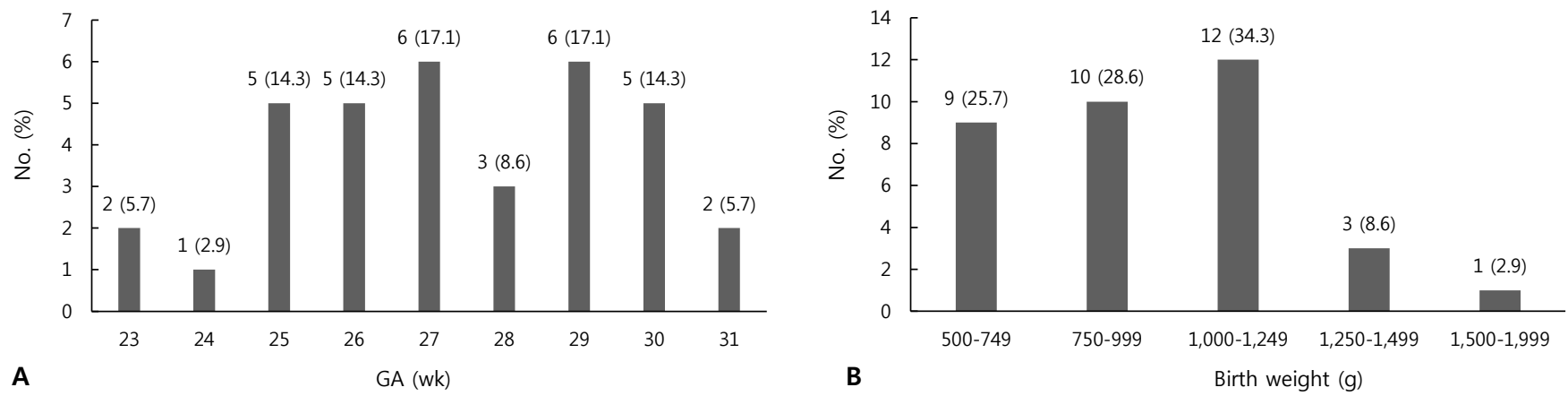

Figure 2. (A) Gestational age (GA) and (B) birth weight distribution of 35 infants with late-onset circulatory collapse (LCC). 
전후로 뇌 초음파에서 새로운 병변이 확인된 경우는 총 7 명(20.0\%) 에서 있었는데 이 중에 1 명에서 퇴원 전에 시행한 뇌 자기공명영상 검사에서 비-낭종성 뇌실주변백질연화증(non-cystic periventricular leukomalacia)이 확인되었다 ${ }^{29)}$. 하이드로코티손 첫 투여 직전의 혈청 코티졸 농도는 $11.4 \pm 1.0 \mu \mathrm{g} / \mathrm{dL}$ 이었고, 하이드로코티손은 총 $21.5 \pm 8.0$ 일간 투여되었고, 총 누적용량은 $33.6 \pm 6.7 \mathrm{mg} / \mathrm{kg}$ 이었으 며, 월경 후 나이 $33^{+4} \pm 0^{+5}$ 주에 투약이 중단되었다(Table 2).

\section{4. 불응성 후기순환부전에서의 부신기능}

LCC가 발생하였던 35명의 조산아들 중 18명(51.4\%)은 refractory LCC의 정의에 부합하였다. Refractory LCC가 있었던 18 명 중 10 명에 서 저용량 $\mathrm{ACTH}$ 자극검사가 시행되었는데, 이 중 7 명은 예정된 스 케줄에 따라 하이드로코티손을 감량하는 도중에 저혈압이 재발하 여 다시 하이드로코티손을 증량하였다가 이후 다시 감량 및 투약 종
료하였고, 1 명은 LCC가 시간 차를 두고 2회 발생하여 하이드로코티 손 투여 스케줄을 2 차례 시행하였으며, 나머지 2명은 하이드로코티 손을 중단하지 못하여 경구용 하이드로코티손을 지참하고 퇴원하였 다. 이 10 명에서의 기저 혈청 코티졸 농도는 $3.09 \pm 2.70 \mu \mathrm{g} / \mathrm{dL}$ 이었 고, 이들 중 3 명 $30 \%)$ 에서 $\mathrm{ACTH}$ 에 대한 불충분한 부신피질 반응이 확인되었다. 저용량 ACTH 자극검사의 결과는 Table 3에 기술하였 다.

\section{고찰}

조산아에서 저혈압은 아직 정의가 명확하지 않고 각 센터별로 진 단 및 치료 기준이 다르지만, 신생아중환자실에서 흔하게 접하는 문 제이다 ${ }^{1,3,5,20)}$. 출생 첫 24 시간 이내의 평균혈압 최소 허용수치는 경

Table 2. Clinical Characteristics of 35 Preterm Infants with Late-Onset Circulatory Collapse

\begin{tabular}{|c|c|}
\hline Characteristic & Value \\
\hline \multicolumn{2}{|l|}{ Onset time of LCC } \\
\hline $\operatorname{PND}(\mathrm{d})$ & $18(7-55)$ \\
\hline PMA (wk) & $30^{+5}\left(24^{+6}-34^{+0}\right)$ \\
\hline Weight (g) & $1,200(600-1,500)$ \\
\hline \multicolumn{2}{|l|}{ Clinical features during the LCC event } \\
\hline Baseline MBP ( $<48 \mathrm{hr}$ before the first HCS administration) $(\mathrm{mm} \mathrm{Hg})$ & $43(37-55)$ \\
\hline $\mathrm{MBP}$ at the time of the first $\mathrm{HCS}$ administration $(\mathrm{mm} \mathrm{Hg})$ & $31(17-41)$ \\
\hline Degree of MBP drop* $(\%)$ & $32.1(5-61)$ \\
\hline Time interval from hypotension to the first HCS administration (hr) & $2.8 \pm 1.8(1-8)$ \\
\hline Time interval from the first HCS admin. to the recovery of hypotension (hr) & $6.3 \pm 4.9(1-27)$ \\
\hline \multicolumn{2}{|l|}{ Oliguria } \\
\hline Pre-existing ( $<6 \mathrm{hr}$ before the first HCS administration) & $16(45.7)$ \\
\hline Around the LCC event ( -6 to $6 \mathrm{hr}$ from the first HCS administration) & $35(100.0)$ \\
\hline Prolonged (6-24 hr after the first HCS administration) & $3(8.6)$ \\
\hline \multicolumn{2}{|l|}{ Electrolyte imbalances (hypoNa+ or hyperK+) } \\
\hline Pre-existing ( $<24 \mathrm{hr}$ before the first HCS administration.) & $7(20.0)$ \\
\hline Around the LCC event ( -24 to $24 \mathrm{hr}$ from the first HCS administration) & $29(82.9)$ \\
\hline Late ( $\geq 24 \mathrm{hr}$ after the first HCS administration) & $6(17.1)$ \\
\hline \multicolumn{2}{|l|}{ Adverse events around LCC event } \\
\hline Step-up of respiratory supports & $8(22.9)$ \\
\hline New findings on brain ultrasound & $7(20.0)$ \\
\hline \multicolumn{2}{|l|}{ Associated endocrinologic factors } \\
\hline Baseline serum cortisol $(\mu \mathrm{g} / \mathrm{dL})$ & $11.4 \pm 1.0$ \\
\hline Total HCS accumulated dose (mg/kg) & $33.6 \pm 6.7$ \\
\hline Total duration of HCS administration (d) & $21.5 \pm 8.0$ \\
\hline Time of the last HCS administration (PMA in wk) & $33^{+4} \pm 0^{+5}$ \\
\hline
\end{tabular}

Values are expressed as median (range), mean \pm standard deviation (range), number (\%), or mean \pm standard deviation.

*(Baseline MBP- MBP at the time of the first HCS administration)/baseline MBP $\times 100$.

Abbreviations: LCC, late-onset circulatory collapse; PND, postnatal day; PMA, post-menstrual age; MBP, mean blood pressure; HCS, hydrocortisone. 
Table 3. Clinical Characteristics of Preterm Infants with Refractory Late-Onset Circulatory Collapse Who Underwent the Low-Dose Adrenocorticotropic Hormone Stimulation Test

\begin{tabular}{|c|c|c|c|c|c|}
\hline \multirow{2}{*}{ Patient } & \multirow{2}{*}{ GA/BW (wk/g) } & \multirow{2}{*}{ PND at test (d) } & \multirow{2}{*}{ PMA at test (wk) } & \multicolumn{2}{|c|}{ Serum cortisol $(\mu \mathrm{g} / \mathrm{dL})$} \\
\hline & & & & Basal & After $30 \mathrm{~min}$ \\
\hline 1 & $26^{+2} / 700$ & 71 & $36^{+3}$ & 0.8 & 10.4 \\
\hline 3 & $25^{+5} / 640$ & 108 & $41^{+1}$ & 2.1 & 26 \\
\hline 4 & $27^{+6} / 1,100$ & 53 & $35^{+3}$ & 1.8 & 16.8 \\
\hline 7 & $30^{+3} / 1,370$ & 33 & $35^{+1}$ & 1.8 & 19.2 \\
\hline 8 & $25^{+0} / 740$ & 104 & $39^{+5}$ & 10.1 & 20.9 \\
\hline 9 & $26^{+4} / 610$ & 36 & $31^{+5}$ & 2.9 & 3.4 \\
\hline 10 & $27^{+2} / 940$ & 16 & $29^{+3}$ & 4.9 & 11.4 \\
\hline
\end{tabular}

Refractory late-onset circulatory collapse ( $\mathrm{n}=18)$ : low dose adrenocorticotropic hormone stimulation test $(\mathrm{n}=10)$; endocrinologic evidence of hypothalamic-pituitary-adrenal axis suppression $(\mathrm{n}=3)$.

Abbreviations: GA, gestational age; BW, birth weight; PND, postnatal day; PMA, postmenstrual age.

험적으로 출생 시 임신나이를 적용해 왔다 ${ }^{30}$. 출생 후 조산아의 평 균혈압은 서서히 상승하는데 생후 72 시간 이후로는 일반적으로 30 $\mathrm{mm} \mathrm{Hg}$ 이상으로 유지되는 것으로 알려져 있다 ${ }^{31}$. 그러나 재태주령 에 따른 혈압의 백분위수로 저혈압을 정의하였을 때, 같은 재태주수 의 조산아라 할지라도, 같은 혈압수치가 각자에게 동일한 전신혈액 순환 및 조직관류를 보장하는 것이 아님이 경험적으로 확인하였다 ${ }^{19)}$. 또한 정상혈압을 유지하고 있음에도 불구하고 순환부전, 즉 부적 절한 전신혈액순환 및 조직관류 상태가 발생하는 경우도 보고되어 있다 ${ }^{23)}$.

따라서 조산아에서 혈압 조절의 목표는 단순히 일정 수치 이상을 유지하는 것이 아니라 뇌를 포함한 주요장기로의 적절한 조직관류 가 보장되는 상태를 유지하는 것이라고 할 수 있다.

초극소 저체중출생아에서 뇌 혈류의 자동조절기능, 즉 전신 평균 혈압이 변화함에도 불구하고 뇌 혈류가 일정하게 유지될 수 있는 평 균혈압의 임계치는 대개 $30 \mathrm{~mm} \mathrm{Hg}$ 전후로 알려져 있다 ${ }^{23,31)}$. 이에 본 연구에서도 저혈압을 평균혈압이 $30 \mathrm{~mm} \mathrm{Hg}$ 이하 또는 이완기 혈압 $20 \mathrm{~mm} \mathrm{Hg}$ 이하이면서 조직관류 저하를 반영하는 핍뇨를 동반하는 경우로 정의하였다.

본 연구에서 임신나이 32 주 미만으로 태어난 조산아 총 303 명 중 65명(21.5\%)에서 생후 7일 이후에 핍뇨를 동반하는 저혈압이 발생 하였고 이들 중 30 명 $(46.2 \%)$ 에서는 순환부전의 원인을 확인할 수 있 었고, 패혈증, 괴사성 장염, 동맥관개존증, 폐동맥고혈압 등이 그 원 인이었다. 이는 기존 연구와 비슷한 결과로써 Subhedar ${ }^{32}$ 에 의하면 극소 저체중출생아의 약 $30 \%$ 에서 저혈압이 발생하는 것으로 보고 하였고, Al-Aweel 등 ${ }^{4)}$ 은 저혈압의 빈도를 24\%- $45 \%$ 로 보고하였다. 이러한 저혈압의 원인은 패혈증, 저혈량성 쇼크, 대량 출혈, 기계환 기로 인한 높은 흥강압 등과 관련이 있는 것으로 알려져 있닿. 이와
반대로 35 명의 조산아들에서 발생한 저혈압은 특별한 원인을 찾을 수 없었고 본 연구의 주된 관심사인 LCC의 정의에 부합하였다. 결 국 생후 7일 이후에 발생한 핍뇨를 동반한 저혈압의 과반수(35/65, $53.8 \%$ )가 LCC에 해당되었다.

LCC는 2000년대부터 일본에서 보고되기 시작한 독특한 임상적 실체로서 Kawai 등에 따르면 LCC의 발생빈도는 극소 저체중출생 아에서 $6.3 \%$, 초극소 저체중출생아에서 $11.6 \%$ 였다 ${ }^{33)}$. 국내에서는 2011년에 본 센터에서 LCC에 대한 첫 보고를 하였는데 32주 미만 의 조산아 중에서의 발생빈도는 $7.6 \%$ 그리고 극소 저체중출생아에 서는 $7.4 \%$ 의 발생빈도를 보였다 ${ }^{19)}$. 임신나이 32 주 미만의 조산아들 을 대상으로 하였던 본 연구에서는 LCC의 발생빈도가 $11.9 \%$ 로 이 전 연구에 비해 높아졌는데 이는 LCC에 대한 임상적 경험이 축적 됨에 따라 진단율이 더 높아진 것이 주된 원인으로 보인다. 2009년 Neonatal Research Network Database in Japan의 자료 ${ }^{16)}$ 에 따르면 임신나이가 이를수록 LCC의 발생빈도가 증가하는 것으로 알려져 있 는데 본 연구에서도 28 주 미만에서 임신나이가 이를수록 LCC의 발 생빈도가 증가하는 것을 확인할 수 있었다. 본 연구에서 LCC가 발생 한 시점의 중앙값은 출생 후 18 일, 월경 후 나이로는 $30^{+5}$ 주이었고 당 시 체중의 중앙값은 $1,200 \mathrm{~g}$ 이었다. 이는 일본의 Masumoto 등 ${ }^{34)}$ 이 보고한 연구 결과와 매우 유사한 결과로 이 연구에서는 LCC가 평균 생후 18 일, 월경 후 나이로는 $30^{+1}$ 주에 발생하였다. 일본에서 보고된 그 외의 다른 연구 결과에서도 LCC의 발생시기는 유사하였다 ${ }^{12,18-20)}$.

본 연구자들의 이전 연구에서는 LCC로 인한 저혈압을 인지한 시 점부터 하이드로코티손이 투여될 때까지 $10.4 \pm 4.6$ 시간이 소요되었 는데 본 연구에서는 $2.8 \pm 1.8$ 시간으로 저혈압의 인지 후 하이드로코 티손이 투약되기까지 걸리는 시간이 빨라졌다. 이는 최근 LCC의 발 생빈도가 증가한 것과 같은 이유로, LCC에 대한 임상적 경험이 축적 
됨에 따라 이전에 비해 LCC를 더 빨리 진단 또는 추정하고 그만큼 하 이드로코티손의 투여도 더 빨라진 것으로 생각된다.

$\mathrm{Ng}$ 등 $^{35}$ 은 무작위 대조실험을 통해서 첫 1주일 이내 발생하는 불 응성 저혈압의 예방 및 치료에 부신피질호르몬의 투여가 효과적임 을 보고하였고 이러한 출생 초기에 발생하는 저혈압의 원인이 시상 하부-뇌하수체-부신 축의 미성숙함으로 인한 부신기능저하와 관련 이 있을 것으로 추정하였다. 본 연구에서는 생후 첫 24 시간 이내의 저혈압의 발생빈도가 LCC군에서 $31.4 \%$ 로, non-LCC 저혈압군에서 의 $26.7 \%$ 에 비해 높았으나 통계적 유의성은 없었다. 주로 생후 7 일 이후에 발생하는 LCC가 이러한 출생 초기의 부신기능저하와 관련이 있는지에 대해서는 아직 알려진 바가 없다. 그러나 본 연구에서 저 용량 ACTH 자극검사를 시행한 10 명의 refractory LCC 환아들 중 3 명 에서 부신기능부전의 내분비학적 증거가 있었던 것으로 보아 적어 도 심한 형태의 LCC의 일부는 실제로 부신기능부전과 관련이 있을 가능성이 있다.

LCC군과 non-LCC 저혈압군 간의 주산기 및 신생아기의 임상적 특성을 비교해보았을 때, 두 군 간에 임신나이, 출생체중, 성별 등의 기본적인 인구학적 특성에는 유의한 차이가 없었으나 LCC군에서 부 당경량아였던 경우는 유의하게 적었고 다태아였던 경우는 유의하 게 많았다. 또한 LCC군에 비해 non-LCC 저혈압군에서 폐동맥고혈 압, 폐출혈, 폐혈증이 유의하게 많이 발생하였는데 이는 해당 인자 가 non-LCC 저혈압군에서 저혈압의 직접적인 원인이었기 때문으로 생각되었다. 또한 LCC군에서 중증 기관지폐이형성증의 발생률과 사망률이 상대적으로 낮았는데, 이는 LCC군에서의 저혈압이 치료 에 대한 반응이 더 좋았기 때문일 것으로 생각된다. 실제로 다수의 연구들에서 LCC는 가능한 조기에 진단 또는 의심하고 신속하게 하 이드로코티손을 투여했을 때, 주요 장기의 심각한 손상 없이 순환부 전이 회복될 수 있음을 보고하였다 ${ }^{12,19,20)}$. 앞서 연구방법에서 언급된 바와 같이 본 연구자들의 병원에서는 표준화된 프로토콜에 따라 순 환부전에 대한 신속한 처치를 하고 있는데, 특히 LCC의 경우, 하이 드로코티손의 투여가 신속히 이루어짐으로써 순환부전 상태가 오래 지속되지 않고 바로 회복되었기 때문에 저혈압의 원인이 다양하고 치료에 대한 반응도 예측하기 어려운 non-LCC 저혈압군에 비해 중 증 기관지폐이형성증의 발생률 및 사망률이 낮았을 것으로 생각된 다.

본 연구에서는 LCC가 발생한 7명의 조산아들에서 저혈압 전후로 뇌 초음파에서 새로운 병변이 발생한 것이 확인되었고 이 중 1 명은 퇴원 전에 시행한 뇌 자기공명영상에서 비-낭종성 뇌실주위백질연 화증이 확인되었다. Nakanishi 등 ${ }^{36)}$ 의 연구에 따르면, 임신나이 32 주 미만 조산아의 약 $11 \%$ 에서 LCC가 진단되었고 LCC가 발생하지 않았던 조산아에 비해 LCC가 발생하였던 조산아들에서 중증 뇌실내 출혈, 기관지폐이형성증 뇌실주위백질연화증과 뇌성마비의 발생빈 도가 높았고 기계환기 기간, 산소투여 기간 및 입원 기간이 더 길었
다. 따라서 LCC에 대한 신속하고 적극적인 치료가 조산아의 장기적 인 예후를 개선하는 데에 매우 중요할 것으로 생각된다.

병태생리학적 관점에서 LCC의 발생기전은 여전히 명확히 밝혀지 지 않았으나 시상하부-뇌하수체-부신 축의 미성숙함과 상대적인 부 신기능저하가 관련되어 있을 것으로 추정되고 있다 ${ }^{15,16)}$. 일부 연구 에 따르면 출생 초기의 낮은 혈청 코티졸 농도가 저혈압의 발생 및 수축촉진제의 사용과 관련이 있는 것으로 알려졌다 ${ }^{12)}$. Noori 등 ${ }^{6)}$ 은 적정 혈압을 유지하기 위해서 $15 \mu \mathrm{g} / \mathrm{kg} / \mathrm{min}$ 이상의 고용량의 도파 민을 필요로 했던 조산아들에게 하이드로코티손 $2 \mathrm{mg} / \mathrm{kg} / \mathrm{dose}$ 를 정맥주사 하였을 때 혈압, 전신조직관류 및 뇌와 신장의 관류가 개선 되는 것을 확인하였고 Choi 등 ${ }^{19)}$ 의 연구에서도 불응성 저혈압 상태 에서 하이드로코티손을 투여하였을 때 신속한 혈압상승, 소변량 증 가 및 전해질 이상의 개선 효과가 확인되었다.

낮은 혈청 코티졸 농도와 하이드로코티손에 대한 신속하고 일관 된 반응은 부신기능저하가 LCC의 주요 발생기전 중의 하나임을 뒷 받침하는 근거라고 할 수 있다.

최근 질병 상태의 성인이나 소아에서 혈청 코티졸 농도가 $15 \mu \mathrm{g} /$ $\mathrm{dL}$ 이하일 때 상대적인 부신기능부전이 있다고 정의하는 경우가 많 은데, 조산아에서도 코티졸 농도가 $15 \mu \mathrm{g} / \mathrm{dL}$ 미만일 때 상대적인 부 신기능부전이 있는 것으로 생각해야 한다는 주장이 있다 ${ }^{19,37)}$. 본 연 구에서도 LCC가 발생한 조산아들에서 하이드로코티손 투여 직전에 측정한 혈청 코티졸 농도는 $11.4 \pm 1.0 \mu \mathrm{g} / \mathrm{dL}$ 로 본 연구자들이 이전 에 보고한 것과 유사한 결과였다 $(11.6 \pm 4.1 \mu \mathrm{g} / \mathrm{dL})^{19)}$. 이와는 반대로 Masumoto 등 ${ }^{18)}$ 은 LCC가 코티졸의 절대적 결핍에 의한 현상이기보 다는 스트레스에 반응하여 코티졸을 합성하는 능력이 충분치 않기 때문에 발생하는 것이라고 주장하였다. 같은 연구진에 의한 최근의 후속 연구에서는 코티졸과 그 전구물질들의 농도를 측정한 결과를 바탕으로 조산아에서의 부신피질 성숙도는 월경 후 나이와 비례하 며 LCC로 진단된 조산아는 월경 후 나이로 32주까지는 스트레스에 대응한 코티졸의 합성능력이 미성숙하다고 보고하였다 ${ }^{34)}$. 그러나 아직 조산아에서 부신기능 및 시상하부-뇌하수체-부신 축에 대한 병 태생리학적인 이해가 부족하고 각 임신나이 별 정상 혈청 코티졸 농 도 및 스테로이드 합성과정에 대한 자료가 여전히 부족한 실정이다.

본 연구는 단일기관에서 수행 된 소규모의 후향적 연구로서 그 결 과의 해석에 제한이 있을 수밖에 없으며 저혈압이 발생한 조산아만 을 연구 대상으로 하였기 때문에 LCC군과 저혈압이 발생하지 않은 조산아 간의 비교 및 LCC와 연관된 위험인자 분석은 하지 못하였다. 또한 주산기 인자와 신생아중환자실 입 원기간 동안에 발생한 사건 만을 조사하였고 퇴원 이후의 장기 신경학적 발달에 대한 자료는 수 집하지 못하였다. 부신기능의 평가를 위한 저용량 $\mathrm{ACTH}$ 자극검사 도 LCC가 발생한 모든 조산아가 아닌 refractory LCC를 보인 조산아 에 한해 시행되었기 때문에 LCC에서의 부신기능에 대한 평가도 충 분히 이루어지지 못한 한계점이 있다. 
그러나 본 연구를 통하여 32주 미만의 조산아에서 발생한 생후 7 일 이후의 저혈압의 약 반 수는 뚜렷한 원인을 찾을 수 없는 LCC에 해당된다는 것을 확인할 수 있었다. LCC는 다른 원인으로 인한 저혈 압과 마찬가지로 뇌실주위백질연화증 및 뇌성마비의 발생과 연관이 있는 것으로 알려져 있으나 하이드로코티손의 투여로 비교적 빠르 게 회복될 수 있기 때문에 가능한 조기에 의심하고 진단하는 것이 중 요할 것으로 생각된다. 이미 LCC에 대한 역학 및 병태생리연구가 활 발한 일본에 비해 아직 국내에서는 LCC에 대한 보고가 드문데 인종 적 유사성을 고려한다면 우리나라에서도 LCC의 발생이 드물지 않을 것으로 추정된다. 또한 LCC는 뇌실주위백질연화증 및 뇌성마비의 발생과도 연관이 있는 것으로 알려져 있기 때문에 적절한 치료가 안 되는 경우 조산아의 장기적인 예후에 부정적인 영향을 줄 가능성이 높다. 따라서 LCC에 대한 전국적인 발생 현황, 각 기관별 발생빈도, 관련된 위험인자 및 장단기 합병증을 파악하기 위한 전향적인 다기 관 연구가 시급히 필요할 것으로 생각된다.

\section{이해관계}

본 저자는 이 논문과 관련된 이해관계가 없음.

\section{REFERENCES}

1. Sahni M, Jain S. Hypotension in neonates. NeoReviews 2016; 17:e579-89.

2. Ahn HS, Shin HY. Pediatrics. 11th ed. Seoul: MiraeN, 2016:7268.

3. Ibrahim CP. Hypotension in preterm infants. Indian Pediatr 2008;45:285-94.

4. Al-Aweel I, Pursley DM, Rubin LP, Shah B, Weisberger S, Richardson DK. Variations in prevalence of hypotension, hypertension, and vasopressor use in NICUs. J Perinatol 2001; 21:272-8.

5. Ng PC, Lam CW, Fok TF, Lee CH, Ma KC, Chan IH, et al. Refractory hypotension in preterm infants with adrenocortical insufficiency. Arch Dis Child Fetal Neonatal Ed 2001;84:F122-4.

6. Noori S, Friedlich P, Wong P, Ebrahimi M, Siassi B, Seri I. Hemodynamic changes after low-dosage hydrocortisone administration in vasopressor-treated preterm and term neonates. Pediatrics 2006;118:1456-66.

7. Helbock HJ, Insoft RM, Conte FA. Glucocorticoid-responsive hypotension in extremely low birth weight newborns. Pediatrics 1993;92:715-7.

8. Fauser A, Pohlandt F, Bartmann P, Gortner L. Rapid increase of blood pressure in extremely low birth weight infants after a single dose of dexamethasone. Eur J Pediatr 1993;152:354-6.

9. Sasidharan P. Role of corticosteroids in neonatal blood pressure homeostasis. Clin Perinatol 1998;25:723-40.

10. Fernandez E, Schrader R, Watterberg K. Prevalence of low cortisol values in term and near-term infants with vasopressorresistant hypotension. J Perinatol 2005;25:114-8.

11. Oshiro M, Yamamoto H, Hosono H. Factors of late-onset circulatory collapse in the early nutrient and electrolyte management of extremely premature infant. J Jpn Soc Perinat Neonatal Med 2006;42:640-7.

12. Shimokaze T, Akaba K, Saito E. Late-onset glucocorticoidresponsive circulatory collapse in preterm infants: clinical characteristics of 14 patients. Tohoku J Exp Med 2015;235:241-8.

13. Seri I, Tan R, Evans J. Cardiovascular effects of hydrocortisone in preterm infants with pressor-resistant hypotension. Pediatrics 2001;107:1070-4.

14. Koyama N, Ohki S, Shirai K, Taihei T, Iwase K, Terasawa S, et al. Epidemiological examination by fact finding-multicenter study of the imperfect circulation (Chronic stage circulatory dysfunction: CSCD) transient for 12 acute phases after secession. J Jpn Soc Prematur Newborn Med 2005;17:412.

15. Kawai M. Late-onset circulatory collapse of prematurity. Pediatr Int 2017;59:391-6.

16. Miwa M, Kusuda S, Ikeda K. Late-onset circulatory collapse in very low-birthweight infants: a Japanese perspective. Neoreviews 2009;10:e381-6.

17. Kobayashi S, Fujimoto S, Koyama N, Fukuda S, Iwaki T, Tanaka $\mathrm{T}$, et al. Late-onset circulatory dysfunction of premature infants and late-onset periventricular leukomalacia. Pediatr Int 2008; 50:225-31

18. Masumoto K, Kusuda S, Aoyagi H, Tamura Y, Obonai T, Yamasaki $\mathrm{C}$, et al. Comparison of serum cortisol concentrations in preterm infants with or without late-onset circulatory collapse due to adrenal insufficiency of prematurity. Pediatr Res 2008;63:686-90.

19. Choi EJ, Sohn JA, Lee EH, Lee JY, Lee HJ, Chung HR, et al. Clinical Picture of Adrenal Insufficiency-associated Hypotension in Preterm Infants. J Korean Soc Neonatol 2011;18:82-8.

20. Lee WJ, Kim MY, Cho HJ, Lee JS, Son DW. Clinical features of late-onset circulatory collapse in preterm infants. Korean J perinatol 2013;24:148-57.

21. Jobe AH, Bancalari E. Bronchopulmonary dysplasia. Am J Respir Crit Care Med 2001;163:1723-9.

22. Papile LA, Burstein J, Burstein R, Koffler H. Incidence and evolution of subependymal and intraventricular hemorrhage: a study of infants with birth weights less than 1,500 gm. J Pediatr 1978;92:529-34.

23. Rhee CJ, Kaiser JR, Rios DR, Kibler KK, Easley RB, Andropoulos 
DB, et al. Elevated diastolic closing margin is associated with intraventricular hemorrhage in premature infants. J Pediatr 2016;174:52-6.

24. Askenazi DJ, Ambalavanan N, Goldstein SL. Acute kidney injury in critically ill newborns: what do we know? What do we need to learn? Pediatr Nephrol 2009;24:265-74.

25. de Vries LS, Eken P, Dubowitz LM. The spectrum of leukomalacia using cranial ultrasound. Behav Brain Res 1992;49:1-6.

26. Chung HR. Adrenal and thyroid function in the fetus and preterm infant. Korean J Pediatr 2014;57:425-33.

27. Watterberg KL, Shaffer ML, Garland JS, Thilo EH, Mammel $\mathrm{MC}$, Couser RJ, et al. Effect of dose on response to adrenocorticotropin in extremely low birth weight infants. J Clin Endocrinol Metab 2005;90:6380-5.

28. Cooper MS, Stewart PM. Adrenal insufficiency in critical illness. J Intensive Care Med 2007;22:348-62.

29. Volpe JJ. Confusions in nomenclature: "periventricular leukomalacia" and "white matter injury": identical, distinct, or overlapping? Pediatr Neurol 2017;73:3-6.

30. Vargo L, Seri I. New NANN practice guideline: the management of hypotension in the very-low-birth-weight infant. Adv Neonatal Care 2011;11:272-8.

31. Fanaroff JM, Fanaroff AA. Blood pressure disorders in the neonate: hypotension and hypertension. Semin Fetal Neonatal
Med 2006;11:174-81.

32. Subhedar NV. Treatment of hypotension in newborns. Semin Neonatol 2003;8:413-23.

33. Kawai M, Kusuda S, Cho K, Horikawa R, Takizawa F, Ono M, et al. Nationwide surveillance of circulatory collapse associated with levothyroxine administration in very-low-birthweight infants in Japan. Pediatr Int 2012;54:177-81.

34. Masumoto K, Tagawa N, Kobayashi Y, Kusuda S. Cortisol production in preterm infants with or without late-onset adrenal insufficiency of prematurity: a prospective observational study. Pediatr Neonatol 2018 Dec 21 [Epub]. https://doi.org/10.1016/ j.pedneo.2018.12.001.

35. Ng PC, Lee CH, Bnur FL, Chan IH, Lee AW, Wong E, et al. A double-blind, randomized, controlled study of a "stress dose" of hydrocortisone for rescue treatment of refractory hypotension in preterm infants. Pediatrics 2006;117:367-75.

36. Nakanishi H, Yamanaka S, Koriyama T, Shishida N, Miyagi N, Kim TJ, et al. Clinical characterization and long-term prognosis of neurological development in preterm infants with late-onset circulatory collapse. J Perinatol 2010;30:751-6.

37. Korte C, Styne D, Merritt TA, Mayes D, Wertz A, Helbock HJ. Adrenocortical function in the very low birth weight infant: improved testing sensitivity and association with neonatal outcome. J Pediatr 1996;128:257-63. 